Sustinere

Journal of Environment and Sustainability

Volume 2 Issue 1 (2018) 1 - 10

Print ISSN: 2549-1245 Online ISSN: 2549-1253

Website: https://sustinerejes.com E-mail: sustinere.jes@iain-surakarta.ac.id

\title{
RESEARCH PAPER \\ Analysis of consumer behavior and energy calculation of the end of life phase on stamped batik products
}

\author{
Much. Djunaidi*, Dyah Ayuningtyas \\ Dept. Industrial Engineering, Universitas Muhammadiyah Surakarta, Indonesia \\ Article history: \\ Received 09 January 2018 | Accepted 17 April 2018 | Available online 05 May 2018
}

\begin{abstract}
A product will enter the end of life phase when the usage period expires. End of life recycleis divided into three categories, namely reuse, recycle, and landfills. Reuse is transferring usage rights to others to be used for the same purpose. Recycle is utilising used goods as raw materials for other products. Landfills are putting used clothing to a garbage dump site. Consumers have different tendencies to the expired product. Stamped batik as a typical product of Solo also experiences the same treatment at the end of its life. This study has the objective of reviewing the consumer behaviour toward the stamp batik and calculating the energy needed in the final product period. Simapro 3.8.0.0 sofwate was used for the analysis. Based on consumer behaviour toward the end of product life, the stamped batik user mostly transfer the function of stamped batik to cleaning cloth or recycle (48.97\%). The energy needed for the recycling process of stamped batik is $3.2 \mathrm{kPt}$. The energy resources of the landfill of stamped batik are $0,085 \mathrm{kPt}$. The electrical energy used for landfills of stamped batik is 14.4 MJ per year.
\end{abstract}

Keywords: Stamped batik; product end of life; consumer behavior; environmental impact

\section{Introduction}

Indonesia is a country with thousands of cultures. One of them is batik. Batik Indonesia has been established as a heritage of humanity for oral and intangible culture (Masterpiece of the Oral and Intangible Heritage of Humanity) by UNESCO since October 2, 2009. Surakarta is one of the cities in Indonesia which has the relatively rapid development of batik industry (Yoshanti, 2017).

Batik is the combination of art and technology. Batik product is a blend of art motif, decoration and colour processed by immersion and decay (Tjokropramono, 2011). Batik products have three types; they are handwriting batik, stamped batik, and printed batik 
(Iskandar, 2016). Stamped batik is a cloth decorated with batik texture and style formed with a stamp (usually made of copper). The process of making this type usually takes two to three days. The raw material of stamped batik is various kinds of fabric, such as unbleached plain fabric, cotton fabric, rayon fabric, and polyester fabric. In general, the cloth that is often used in the batik manufacture is polyester fabric (Nurdalia, 2006; Saicheua, et al., 2012).

The problem in batik industry in Indonesia is the waste. The batik clothing that has been used produces solid waste. Solid waste is the effluent or yield of a process that is solid, muddy and its texture like porridge (Weiner \& Matthews, 2003). Consumer behaviour at the end of life of stamped batik and the step of the end of life influences the environment. The final use of stamped batik products can cause airborne emissions or contamination to the water and soil. There are three different ways of how consumers end the lifetime of stamped batik products, which are giving the products to others to continue the use (reuse), changing the function value (recycle), or disposing the products as waste (landfill) (Cherubini, et al., 2008; Palupi, et al., 2014).

The public awareness of environmental issues is increasing and it forces the businesses and the industry to develop more ecological products, also companies need to inform all stakeholders about their activities in consuming natural resources. The company is also required to notify the emissions generated from the production process, during the use of the product, and up to the product (Nygren \& Antikainen, 2010).The green economic transition has prompted companies to use new tools that promote private corporate entrepreneurship. This development aims to improve the competitiveness of enterprises and to achieve sustainable results. Several environmental assessment methods have been developed to measure the impact of these economic activities. Life cycle assessment (LCA) becomes the most widely spelt out and known (Pecas, et al., 2016).

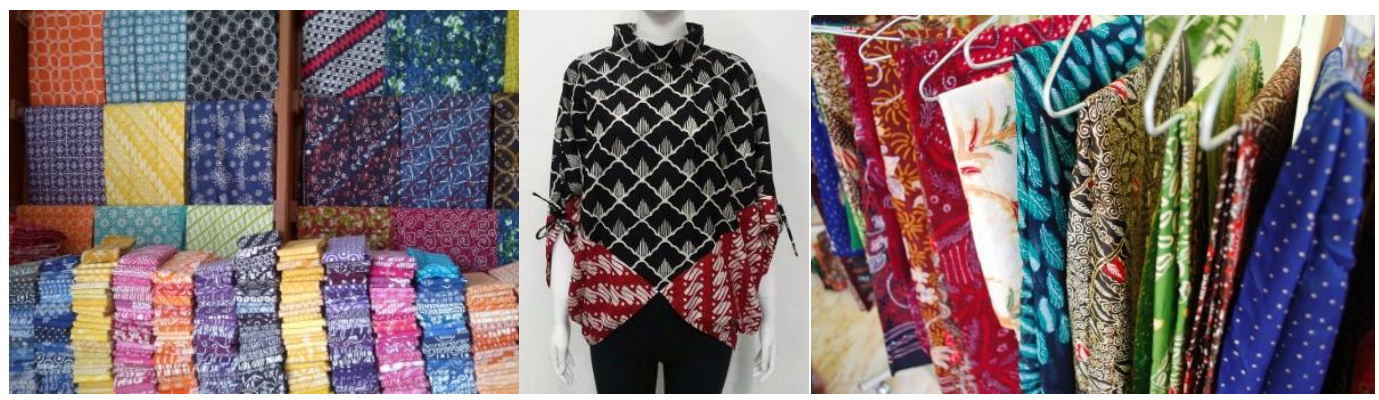

Figure 1. Stamp batik products

Therefore, it is important to identify the final phase of batik clothing products impact on the environment. The investigation of the final use influence of stamp batik products needs to be conducted to determine the emission levels generated. Assessment is done in the final stages of the product lifecycle or the end of life phase (Olivetti, et al., 2010; Carcangiu, et al., 2010). The end of product investigation aims to know the end of the clothes that are not used and is responsible for extending the life of the product (Kara, et al., 2010). 
The benefit of this research is to know how the end of life is chosen by users to end the use of stamped batik (continued by others (reuse), converted into other goods that have function value (recycle), or buried as garbage (landfills)). This study also measures the energy needed to end product life, especially for landfills.

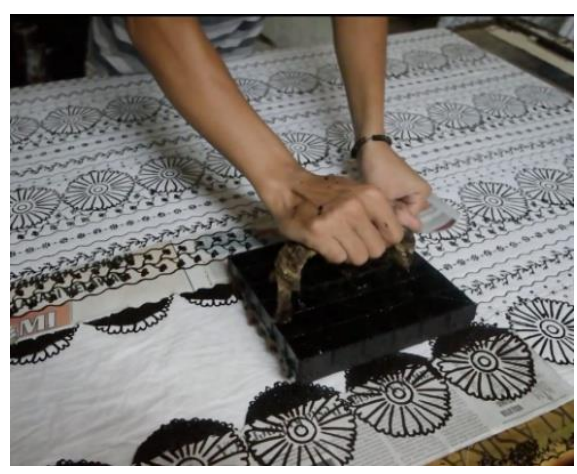

(a)

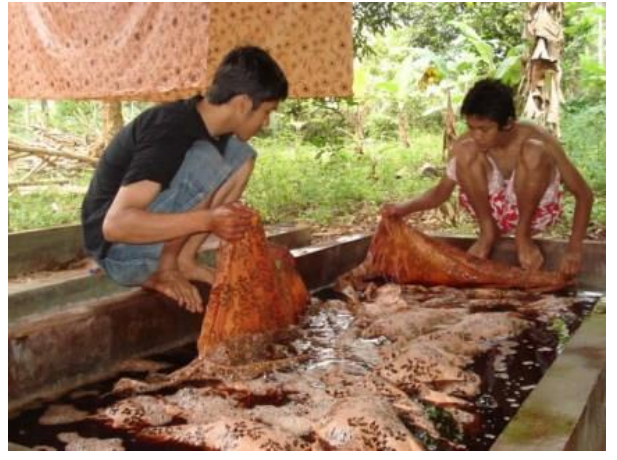

(b)

Figure 2. Stamp batik production process, (a) stamping phase and (b) decay of wax

\section{Life cycle assessment}

Life Cycle Assessment (LCA) is a comprehensive assessment technique to environmental aspects and processes of products. This methodology puts emphasize on the overall life cycle of a product. Assessment starts from the preparation of raw materials to final disposal of the product. LCA has an essential role in the environmental management (Georgakellos, 2002).

Modern business management, which puts emphasize on green innovation, measures the environmental impact of the business activity which uses Life Cycle Assessment (LCA). The LCA study can demonstrate benefits and applications in the areas of strategic planning, product development, production processes, marketing strategies, research and development, social responsibility, and environmental improvement. The insights of green innovation underlie the analysis for product innovation, processes and services. LCA could strengthen the business process management, improve the operations management, promote green innovation, and makes sustainable decisions (Piekarski, et al., 2013).

LCA assesses five stages in the product lifecycle - raw materials, production, distribution, use and end of life-either goods or service (Lehtinen, et al., 2011). The first stage is determining the source of the raw materials of the product or services. The second stage is converting raw materials and assembling them into products. The third stage is distributing the product or service to the user. The fourth stage is focused on usage, where the user will utilise the value of the product or service. The last stage is the end of life which is related to what users do to the product when its use period has ended. The application of an LCA with an assessment on the overall stage is known as the cradle-tograve analysis, as shown in Figure 3. The cradle-to-grave analysis can be used to conduct a comprehensive environmental impact assessment on a product or service. Some analyses which were carried out from raw materials to the completion of the production process until the product is ready for distribution are known as the cradle-to-gate analysis 
(Robertson, et al., 2012). The analysis was also performed with a cradle-to-cradle analysis, as shown in Figure 4.

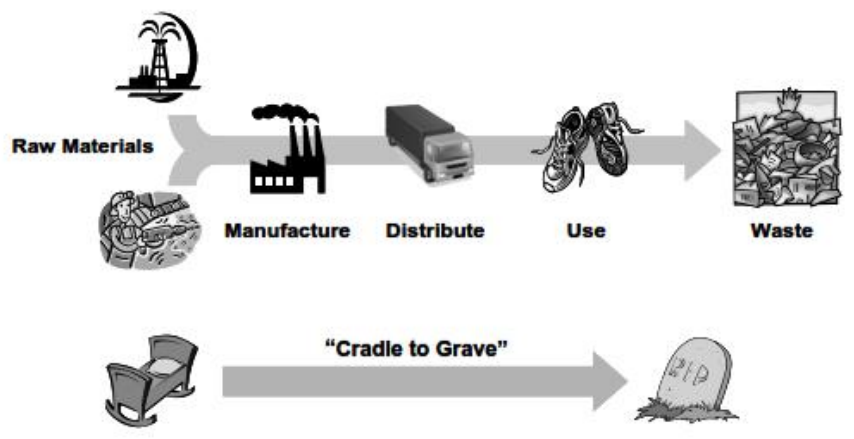

Figure 3. A 'cradle to grave' approach to analysing the life cycle of a product or service (Lehtinen et al., 2011)

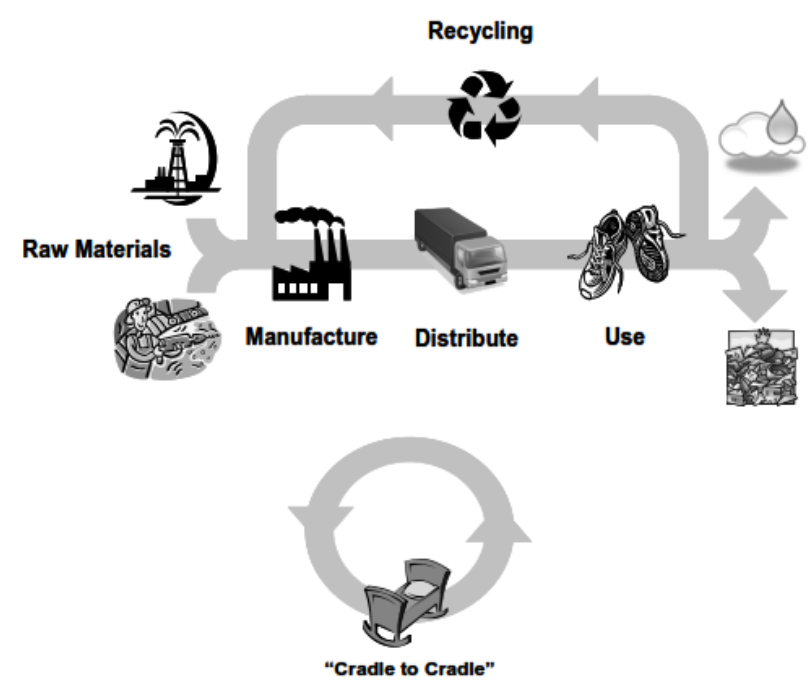

Figure 4. A 'cradle to cradle' approach to analyse the life cycle of a product or service (Lehtinen et al., 2011)

\section{Methods}

Research on user behaviour and energy calculation in the final period of product use wasconducted in five phases. Figure 4 shows the series of activities undertaken for this research.

The first phase was the identification of end of life (EoL) impacts on the environment.At this stage, the identification of the impact of the end of life (EOL) on the environment was conducted through the literature study approach. Researchers researched journals related to the end of life (EOL) and their impact on the environment. Interviews with relevant stakeholders were conducted to verify the data from the literature review. The second phase was designing thequestionnaire. Based on the data obtained from the identification of EoL of stamp batik clothing impact on the environment, the surveypreparation to identify consumer behaviour was based on several phases on EoL. The questionnaires were compiled based on the information obtained frombrainstorming andreviewing related literature in the group discussions. The EoL 
phase consisted of transferring product functions to other users (reuse), recycling clothing (recycle) and disposing of it as waste (landfill). The data was obtained from the identification of consumer behaviour on the impact of EoL phase of stamp batik clothing on the environment. The third phase was creating a profile related to the consumer attitude. After designing the questionnaire to identify the consumer behaviour at the end of the product use, a consumer attitude profile on the impact of stamped batik clothes on the environment was compiled. From the questionnaire, consumer behaviour on EoL on the use of batik clothing was identified. Consumer treatment is very influential in minimising or maximising the impact of stamped batik clothes on the environment. The consumer behaviour data on the EoL which were identified include reuse, recycle and landfill.

The fourth phase is the analysis of the data obtained from the questionnaire. After creating a profile of consumer attitude on batik clothes cap on the EoL phase, the data from the questionnaire were analysed. The data in the questionnaire are the information given by consumers about the way they treat batik clothing by using the EoL phase. The stamped batik' impactresulted in the environment is tremendous, and it is necessary to convert the effect of EoL batik clothing on the cost of the environmental impact. The questionnaire was analysed by using the descriptive statistical approach and SimaPro software. The last phase is withdrawing the conclusion. After analysing the data in the questionnaire, the researcher identified the consumer's common attitudes in the EoL phase, and the most significant percentage in the EoL phase, and the costs incurred on the environment were also identified. Following is the overall results that have been obtained.

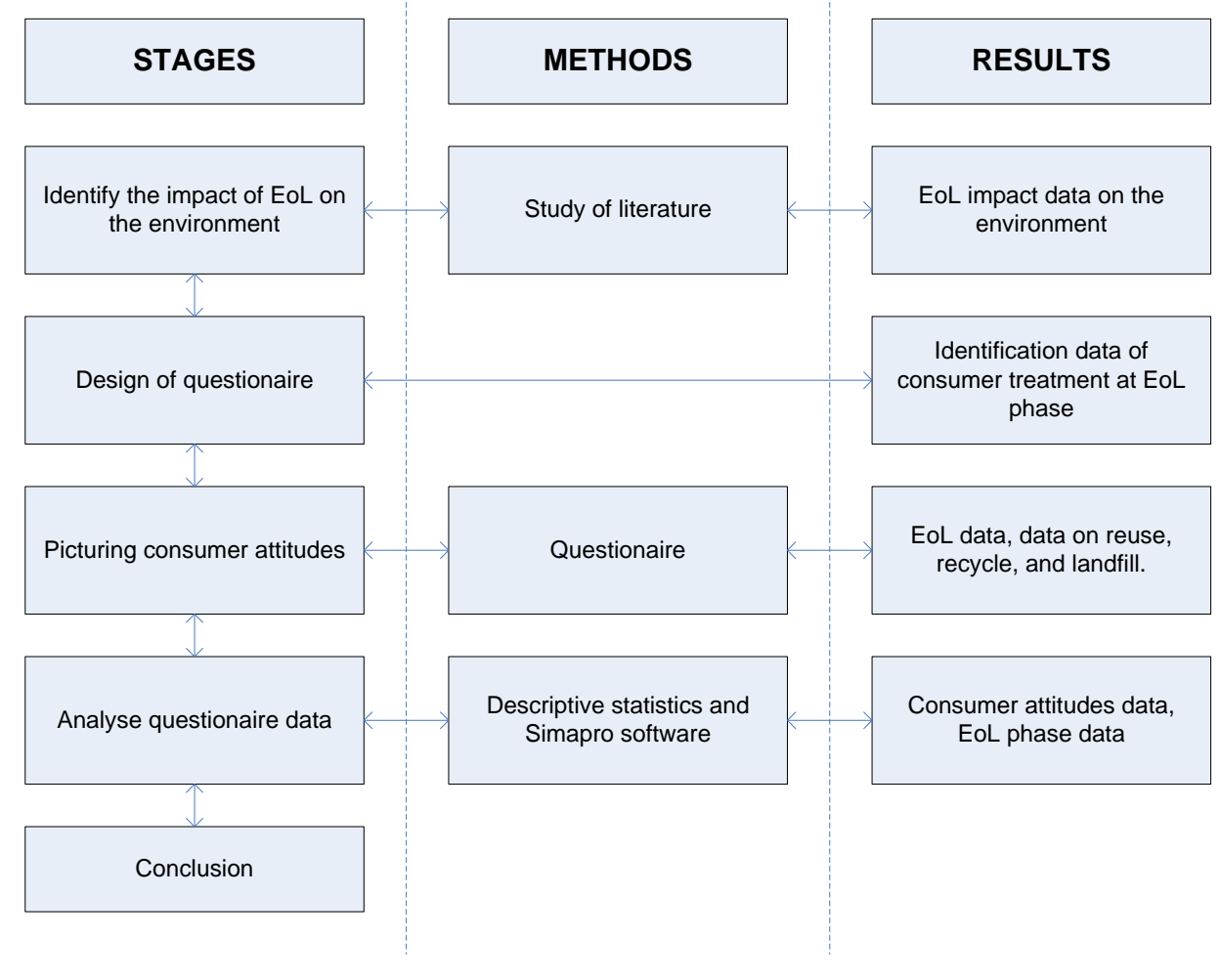

Figure 5. Research flowchart 


\section{Result and Discussion}

\section{Data Interpretation}

The data collection was collected from 250 respondents. Respondents are the owners of batik clothing (stamped batik' end of life was in 2017). Questionnaires were distributed via online by using google apps. Respondents filled out questionnaires via online. The questionnaire contains questions related to methods in EoL, i.e. reuse, recycle and landfill. Respondents may answer each type of product termination under their respective experience. Respondents gave a response of 580 treatments, as shown in Table 1.

Tabel 1. Customer behaviour on end of life stage

\begin{tabular}{lrc}
\hline End of Life & Frequency & Percentage (\%) \\
\hline Behaviour & 199 & 34.31 \\
Reuse 1 & 0 & 0.00 \\
Reuse 2 & 27 & 4.66 \\
Reuse 3 & 284 & 48.97 \\
Recycle & 10 & 1.72 \\
Landfill 1 & 60 & 10.34 \\
Landfill 2 & 580 & 100.00 \\
\hline Total & &
\end{tabular}

Through the online questionnaire, most of the respondents were students with an age range of between 16 and 25 years. The total number of respondents were 250 , men were $134(53.6 \%)$ and women were 116 (46.4\%). Related to the age classification, 92\% of respondents were teenagers (17 to 25 years old) - 230 respondents. In terms of the job, most respondents -175 (70\%)-, were students. Respondents stopped the use of batik clothing, mainly due to its size which was no more fit to their body were 96 respondents (38.4\%). Most stamped batik users (48.97\%) changed its function into a cleaning tool or recycle (284 out of 580 treatments).

\section{Calculation of the environmental impact of the recycling activity}

Data were processed by using software Simapro 8.3.0.0 with Ecological Scarcity 2013 VI v1: 04 method. The output variables of Simapro software 8.3.0.0, are: main water pollutants, global warming, radioactive waste deposit, energy resources, heavy metal into the air, carcinogenic substance into the air, mineral resources, heavy metal into water, water pollutants, land use, POP into water, water resources, heavy metal into soil, radioactive substances into water, non-radioactive waste deposit, ozone layer depletion, pesticides into dirt, radioactive substances into water, and noise.

Respondents normally do the recycle treatment for 284 times. The average weight of 30 samples of batik clothes was $0.35 \mathrm{~kg}$. Thus, the entire batik clothes which were recycled were $99.4 \mathrm{~kg}$.

Table 2 describes the results of the Simapro software analysis of the environmental impact characterization assessment of the recycling activity of batik clothing which was $141 \mathrm{kPt}$. The most significant impact was air pollution which was $91.3 \mathrm{kPt}$. Meanwhile, global warming and radioactive wastes were $37.6 \mathrm{kPt}$ and $4.4 \mathrm{kPt}$ respectively. The fourth 
effect is the energy source which was $3.2 \mathrm{kPt}$. While the smallest one was the substance of radioactive emitted into the air which was $4.28 \times 10^{-7} \mathrm{kPt}$ or $0.000428 \mathrm{Pt}$ (the condition did not produce noise at all). The contribution of the $3.2 \mathrm{kPt}$ recycle energy source was $3.12 \%$ of all impacts caused by the recycling activity.

Table2. Characterization assessment of recycling activities

\begin{tabular}{|c|c|c|}
\hline Impact Category & Unit & Total \\
\hline Main air pollutants and PM & $\mathrm{kPt}$ & 9.3 \\
\hline Global Warming & $\mathrm{kPt}$ & 37.6 \\
\hline Radioactive waste deposit & $\mathrm{kPt}$ & 4.4 \\
\hline Energy resources & $\mathrm{kPt}$ & 3.2 \\
\hline Heavy metal into the air & $\mathrm{kPt}$ & 1.72 \\
\hline The carcinogenic substance in air & $\mathrm{kPt}$ & 1.33 \\
\hline Mineral resources & $\mathrm{kPt}$ & 0.365 \\
\hline Heavy metal into water & $\mathrm{kPt}$ & 0.355 \\
\hline Water pollutants & $\mathrm{kPt}$ & 0.296 \\
\hline Land use & $\mathrm{kPt}$ & 0.282 \\
\hline POP into water & $\mathrm{kPt}$ & 0.173 \\
\hline Water resource & $\mathrm{kPt}$ & 0.15 \\
\hline Heavy metal into soil & $\mathrm{kPt}$ & 0.0711 \\
\hline Radioactive substances in water & $\mathrm{kPt}$ & 0.0488 \\
\hline Non-radioactive waste deposit & $\mathrm{kPt}$ & 0.0254 \\
\hline Ozone layer depletion & $\mathrm{kPt}$ & 0.0145 \\
\hline Pesticides in soil & $\mathrm{kPt}$ & 0.00288 \\
\hline Radioactive substances into the air & $\mathrm{kPt}$ & 0.000000428 \\
\hline Noise & $\mathrm{kPt}$ & $\mathrm{X}$ \\
\hline
\end{tabular}

The above calculation shows that ending the use of $99.4 \mathrm{~kg}$ stamped batik products by recycling will produce the same emission level with the one produced 141 people. Consumer behavior on recycling this led the occurrence of air pollution becoming dominant (91 people). That recycling behavior will also affect global warming (37 people).

\section{Calculation of the environmental impact of the landfill activity}

Respondents performed landfill treatment for 70 times. The average weight of 30 samples of batik clothes is $0.35 \mathrm{~kg}$. Thus, the entire batik clothes which were landfilled were $24.5 \mathrm{~kg}$.

Table 3 describes the results the analysis of the Simapro software with regard the environmental impact characterisation assessment of the landfill activity of batik clothing, 
which was $2.1 \mathrm{kPt}$. The enormous impact is the air pollution which was $1.79 \mathrm{kPt}$. Meanwhile, carcinogenic substance emitted into air and energy resources were $0.165 \mathrm{kPt}$ and $0.085 \mathrm{kPt}$ respectively. The fourth effect is the heavy metal resulted in the soil which was $0.0189 \mathrm{kPt}$. While the smallest one is the substance of radioactive emitted into the air that was $4.7 \times 10^{-9} \mathrm{kPt}$ or $0.000047 \mathrm{Pt}$, where the condition does not produce noise at all. The contribution of the recycle energy source of $3.2 \mathrm{kPt}$ was $4.04 \%$ of all impacts caused by the recycling activity.

Tabel 3. Characterization assessment of landfill activities

\begin{tabular}{llll}
\hline \multicolumn{1}{c}{ Impact Category } & Unit & Total & $\begin{array}{c}\text { Landfill of } \\
\text { textiles }\end{array}$ \\
\hline Main air pollutants and PM & $\mathrm{kPt}$ & 1.79 & 1.79 \\
The carcinogenic substance in air & $\mathrm{kPt}$ & 0.165 & 0.165 \\
Energy resources & $\mathrm{kPt}$ & 0.085 & 0.085 \\
Heavy metal into soil & $\mathrm{kPt}$ & 0.0189 & 0.0189 \\
Global Warming & $\mathrm{kPt}$ & 0.0137 & 0.0137 \\
Mineral resources & $\mathrm{kPt}$ & 0.00798 & 0.00798 \\
Heavy metal into water & $\mathrm{kPt}$ & 0.00781 & 0.00781 \\
Heavy metal into the air & $\mathrm{kPt}$ & 0.00682 & 0.00682 \\
Ozone layer depletion & $\mathrm{kPt}$ & 0.000676 & 0.00068 \\
Water Pollutants & $\mathrm{kPt}$ & 0.000499 & 0.0005 \\
Water resource & $\mathrm{kPt}$ & 0.000455 & 0.00046 \\
Radioactive substances into the air & $\mathrm{kPt}$ & $4.7 \mathrm{E}-09$ & $4.7 \mathrm{E}-09$ \\
Noise & $\mathrm{kPt}$ & $\mathrm{x}$ & $\mathrm{X}$ \\
\hline
\end{tabular}

Figure 6 illustrates the classification of the impacts of landfill activity. The $24.5 \mathrm{~kg}$ buried cape garment produces $5.11 \times 10^{-7} \mathrm{~kg}$ of low radioactive Calcium Fluoride (CaF2), $3.03 \times 10^{-9} \mathrm{~kg}$ dummy plutonium product residue, $2.28 \times 10^{-6} \mathrm{~kg}$ uranium conversion, $3.03 \times 10^{-6} \mathrm{~kg}$ of radioactive waste, $3.5 \times 10^{-6} \mathrm{~kg}$ of uranium depleted, and $14.4 \mathrm{MJ}$ of electrical waste from the garbage burial e.g. gas, air conditioner and others. This indicates that $25.4 \mathrm{~kg}$ of stamped batik waste which was burned yielded only relatively small solid pollutants.

The landfill activities by the respondents were 70 treatments (about $24.5 \mathrm{~kg}$ ). The electrical energy required for the landfill activity was $14.4 \mathrm{MJ}$ per year. As the comparison, the energy consumption of a 15-watt lamp in a year is $233,280 \mathrm{MJ}$. This shows that the use of electrical energy in the landfill process of $25.4 \mathrm{~kg}$ of consumable stamped batik products was equivalent to the electricity usage of 0.0009 -watt lamps in a year. So the energy output is regarded low. 


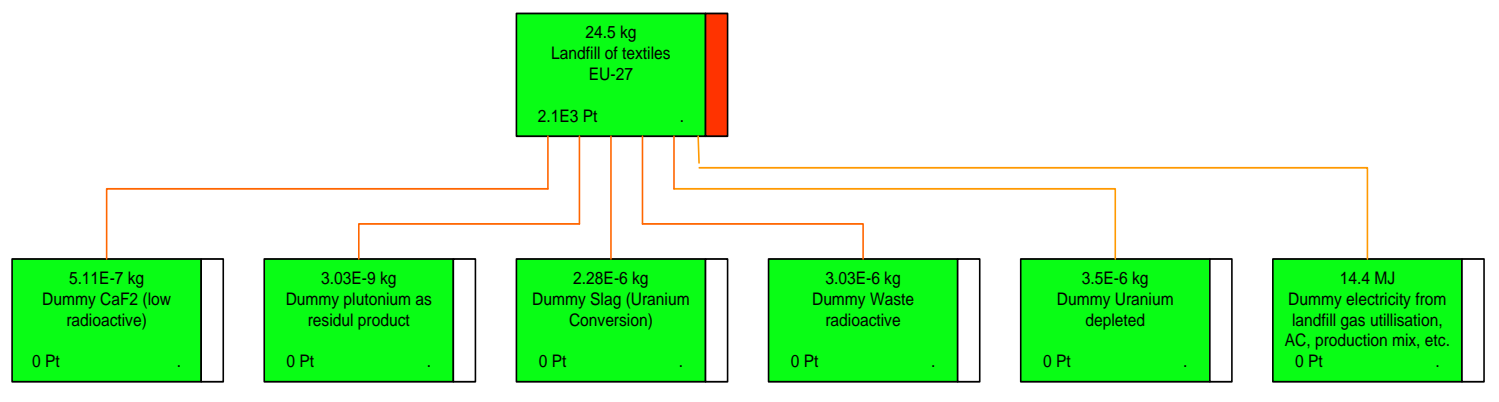

Figure 6. Classification of landfill impacts from stamp batik

\section{Conclusion}

Consumers terminate the use of stamped batik cloth products in three ways, i.e. giving others to continue to use (reuse), taking them as raw materials for other products or uses (recycle), and disposing of them as garbage (landfills). Users between the ages of 17 and 35 tended to recycle (48.97\%) and reuse (38.97\%) them. The landfill was only $12.06 \%$. This discussion shows that landfill treatment at the end of life of stamped batik product is relatively small. Based on calculations using SimaPro, the energy requirement for landfill of batik clothing is only equivalent to the use of electric energy of 1 watt for a year. Also, the value of the impact of burial waste from disposing of stamp batik clothes was small.

\section{References}

Carcangiu, C.E.; Orr`u, P.F.; Pilloni, M.T. (2010). Analysis of End-of-Life Vehicle Processes: A Case Study in Sardinia (Italy). Bruno Vallespir; Th`ecleAlix.International Conference on Advances in Production and Management Systems (APMS), Sep 2009, Paris, France. Springer, IFIP Advances in Information and Communication Technology, AICT338, pp.409-416, 2010, Advances in Production Management Systems. New Challenges, New Approaches.

Cherubini, F.; Bargigli,S.; Ulgiati, S. (2008). "Life Cycle Assesment (LCA) of Waste Management Strategies: Landfilling, Sorting Plant and Inceneration". Energy 34th (2009),pp. 2116-2123

Georgakellos,D.A. (2002)."LCA as a tool for environmental management: A life cycle inventory case study from the Greek Market". Global Nest: The International Journal, Vol.4(2-3), pp.: $93-106$.

Iskandar, I; Kustiyah, E. (2017). "Batik Sebagai Identitas Kultural Bangsa Indonesia di Era Globalisasi”. GEMA, THN XXX/52, Surakarta, pp. 2456 - 2472.

Kara, S.; Manmek, S.; Herrmann, C. (2010). Global manufacturing and the embodied energy of products. CIRP Annals - Manufacturing Technology, Vol. 59 (1), 29 - 32.

Lehtinen, H.; Saarentaus, A.; Rouhiainen, J.; Pitts, M.; Azapagic, A. (2011). A Review of LCA Methods and Tools and their Suitability for SMEs. Europe Innova, Biochem.

Nurdalia, I. (2006). "Study and Analysis Cleaner Production Implementation Opportunity on Small Business of Stamped Batik" (in Bahasa Indonesia:Kajian Dan 
AnalisisPeluangPenerapanProduksiBersihPada Usaha Kecil Batik Cap). Thesis. Magister of Environmental Science, Universityof Diponegoro. Semarang.

Nygren, J.; Antikainen, R. (2010).Use of Life Cycle Assessment (LCA) in Global Companies. Reports. The Finnish Environment Institute 16.

Olivetti, E.; Gregory, J.;Kirchain, R. (2010).Life Cycle Impacts of Alkaline Batteries with A Focus on End-Of-Life. A Study Conducted by The National Electrical Manufacturers Association.

Palupi, A.H.; Tama, I.P.; Sari, R.A. (2014). "Environmental Impact Assessment of Paper Products by Using Life Cycle Assessment (LCA) and Analytic Network Process (ANP)" (in Bahasa Indonesia: "Evaluasi Dampak Lingkungan Produk Kertas dengan Menggunakan Life Cycle Assesment (LCA) dan Analytic Network Process (ANP)". Jurnal Rekayasa dan Manajemen Sistem Industri, Vol. 2 (5), pp.: 1136 - 1146.

Pecas, P.; Gotze, U.; Ribeiro, I.; Schmidt, A.; Symmank, C. (2016). "Life Cycle EngineeringTaxonomy and state of the art". 23rd CIRP Conference on Life Cycle Engineering, Lisbon, Portugal.

Piekarski, M.; da Luz, L.M.; Zocche, L.; de Francisco, A.C. (2013). "Life Cycle Assessment as Entrepreneurial Tool for Business Management and Green Innovations Cassiano". Journal onTechnologyManagement and Innovation, Vol. 8 (1), pp.: 44 - 53.

Robertson, A.B.; Lam, F.C.F.; Cole, R.J. (2012). “A Comparative Cradle-to-Gate Life Cycle Assessment of Mid-Rise Office Building Construction Alternatives: Laminated Timber or Reinforced Concrete". Buildings, Vol. 2, pp.: 245-270.

Saicheua, V.; Cooper, T.; Knox, A. (2012). Public Understanding Towards Sustainable Clothing And The Supply Chain. University of Nottingham Trent, England.

Tjokropramono, G.Y. (2011). "Filsafat Sebagai Dasar Kajian Dalam Penerapan Motif-Motif Seni Batik Klasik.” Prabangkara, 14 (17), pp.: 73 - 81.

Weiner, R.F., Matthews, R.A. (2003). Environmental Engineering.Butterworth Heinemann Publications, 231. doi: 10.1007/S100220100038.

Yoshanti, G.; Dowaki, K. (2017). “Batik Life Cycle Assesment Analysis (LCA) for Improving Batik Small and Medium Enterprises (SMEs) Sustainable Production in Surakarta Indonesia". in Matsumoto, M.; Masui, K.; Fukushige, S.; Kondoh, S. (editors). Sustainable Through Innovation in Product Life Cycle Design.Springer pp.: 997 1008. (doi: 10.1007/978-981-10-0471-1_68).

Yusuf, A. A., \& Francisco, H. (2009). Climate Change Vulnerability Mapping for Southeast Asia Vulnerability Mapping for Southeast Asia. Economy and Environment Program for Southeast Asia (Vol. 181). Singapore. doi: 10.1158/1541-7786.MCR-07-0267 